\title{
Conservative Party policy for planning: caught between the market and local communities
}

\author{
Barry Goodchild* \\ Sheffield Hallam University
}

\begin{abstract}
Abtract
Whether in power or in opposition, the planning policies of the Conservative Party are caught in a tension between the free market and local communities. On one hand, the Conservatives face developers who want to simplify the planning system, speed up decision making and make sufficient land available for economic activities. All this is likely to promote a small government, deregulatory policy agenda that is, in principle at least, distinctive. On the other hand, the Conservatives face local authorities and a Conservative electorate that are keen on conserving local amenities and the local environment and that, as a result, are also keen on promoting effective systems of local consultation and effective mechanisms of development control. The tension between the market and local communities has been recurrent in Conservative planning policy since at least the 1980s and is unlikely to disappear in the near future. The tension also means, however, that Conservative proposals tend to be relatively narrow in their scope.
\end{abstract}

Keywords: Conservative Party, town planning, environment.

The electoral system in Britain encourages the two main prospective government parties, Labour and Conservative, to attempt to differentiate and distance their proposals and policies from each other. At the same time, there are always limits to any such differentiation and distancing. Prospective governments have to tackle similar problems and have to come up with proposals that satisfy their electorate, satisfy relevant pressure groups and are also practical in terms of their economic impact. In this context, Conservative Party statements and Conservative governments have, since 1945, seldom challenged the case for town planning in the narrow sense of public regulation over the process of land development. They have realised that people care about the neighbourhoods and environment in which they live and that, in addition, a framework of plans helps to co-ordinate public investment and to reduce uncertainties in the land market. Instead, for many years and certainly until the 1980s, the main objective of Conservative policy was to limit publicly-led development, other than in cases of obvious market failure and, above all, to stop any exercise that might lead to an expanded programme of public land ownership. 


\section{p. 20. Conservative Party policy for planning: caught between the market and local communities}

The policies pursued by the Thatcher government between 1979 and 1990 provide an example. The Thatcher government repealed previous legislation that enabled land taxation and public land acquisition; it urged and required local authorities and other public bodies to sell off their land holdings to private developers; and it promoted property-led programmes of urban regeneration. However, this same government also left intact the statutory framework of town planning, that is to say the framework of development control and plan making. The Thatcher government talked about reducing the regulatory burden on industry and investigated the possibility of full or partial deregulation of the town planning system. However, after consultation, it stepped back from any such proposal. In terms of electoral politics, the Thatcher government faced a dilemma between favouring its free market principles or the conservationism of the suburbs and the rural shire counties. Partly for this reason and partly owing to a growing awareness of broader environmental issues, the so-called plan-led system, introduced under a Conservative government in the Town and Country Planning Act, 1990, effectively strengthened the regulatory framework, compared to the system inherited in 1979 (Allmendinger and Thomas H, 1998). The only legacy of the deregulatory measures was the creation of small-scale, experimental and now largely forgotten 'Enterprise Zones' and 'Simplified Planning Zones'.

The subsequent history of party politics in Britain has not repeated the pattern of the post-war period. The 'New' Labour government of Blair and Brown made no effort to introduce additional measures of land taxation or to encourage public land ownership. New Labour also made little effort to give local authorities additional powers to undertake property development and 'positive' planning for large or complex projects. Powers remain weak in comparison to the systems in place in most nearby European countries (Goodchild, 2008: 165; Studdert, 2010). The Labour government, whilst in power, was nevertheless concerned about the slow pace of decision making, about price inflation in the housing market and the apparent failure of the house building industry to respond to inflation through an increase in output. Brown, as Chancellor of the Exchequer, set up an enquiry, the Barker (2004) review, to examine the question and this diagnosed the planning system as the main cause of the problem. Local authorities had failed to allocate a sufficient number of sites for housing development. In response, Labour established national and regional targets for an expanded house building programme. To ensure, moreover, that the policies for land release were implemented by agencies sympathetic to their aims, the Labour government bypassed local authorities in favour of unelected or indirectly elected regional bodies. To ensure the same for large infrastructure projects, notably those relating to transport and energy, the government also established a national Infrastructure Commission.

Much of the content of the Conservative planning policies is a reaction against recent efforts to bypass Conservative and conservationist minded local authorities. In the context of a forthcoming General Election, the draft policies are contained within a series of Conservative party Green Papers and include a reasonable degree of detail on most, though not all the main issues. The main elements are as follows:

- abolition of the regional planning system and of the regional housing targets (Conservative Party, 2009a; 2010)

- abolition of the Infrastructure Commission, though retention of its expertise within an expanded Planning Inspectorate (the body that decides on planning appeals) and the introduction of speeded up enquiry procedures (Conservative Party, 2009a; 2010)

- the introduction of a procedure to ensure that 'the views of local residents are genuinely taken into account at the start of the planning process' (Conservative Party, 2009b) 
- partial deregulation in relation to minor development and the use of buildings in conformity with the provisions of a local plan (Conservative Party, 2010)

- the declassification of gardens as brownfield land in an effort to prevent the 'over-development of neighbourhoods and stop 'garden grabbing' (Conservative Party, 2009b; 2010)

- enhanced restrictions on out-of-town shopping centres, supermarkets and hypermarkets (Conservative Party, 2009c)

- support for measures in favour of renewable energy and environmental sustainability in new building (Conservative Party, 2009b)

- the creation of Community Land Trusts 'a still largely experimental, way for local communities to work together to build sustainable communities which benefit local people' (Conservative Party, 2009b)

- the provision of incentives for new house building 'by matching local authorities' council tax take for each new house built for six years - with special incentives for affordable housing' (Conservative Party, 2009b).

In terms of the dilemma that faced the Thatcher government and despite some references to the loosening of control for minor changes and developments, current Conservative proposals favour the local community rather than the market. Indeed they are deliberately framed within a policy to return power to local communities. The abolition of the regional planning system will almost certainly lead to a return of powers to the shire counties that have previously blocked greenfield development.

The consultation procedures have been described as 'a proposal for a right of appeal for local residents' ('Local Government Chronicle’, 1 February 2010). As stated in the currently published documentation, the proposals do not go that far. They amount instead to consultation prior to the determination of the planning application, with the possibility, in addition, of residents being able to prepare proposals for inclusion in local plans. Decisions will still be decided by the planning authority or on appeal. Even so, the proposals for more local consultation are likely to slow down the process of determining applications and are likely, in addition, to lead local authorities to place more weight on residents' fears and objections. Together with a commitment in favour of high environmental standards in new building, Conservative proposals amount to a low volume and, in terms of design, locally varied house building programme and the end of the expanded national programme envisaged by Barker and then adopted by the Labour government. They amount, moreover, to a low volume programme despite protestations elsewhere about the failure of Labour to ensure the completion of a sufficient number of new homes.

To an extent, the reluctance of local authorities to grant planning permission for housing is countered by a proposal for financial incentives. Local authorities that give planning permission are promised additional funds from central government. It is unclear, however, whether the proposal would amount to redirection of existing sources of infrastructure funding and, linked to this, what level of incentive would be necessary to overcome local objections. Local authorities are already complaining about inadequate investment by central government and, since the start of the recession in 2008 , they are also complaining about the increased reluctance of housing developers to make a contribution to infrastructure costs under existing arrangements.

In another move intended to reduce local opposition, current proposals also refer to measures whereby developers would come to a 'voluntary agreement' to compensate nearby householders for any loss of amenity (Conservative Party, 2010: 13). This particular proposal has raised concerns about the risk of developers 'bribing' influential 
local people and of local residents holding developers to 'ransom'. The legal details will not be easy to resolve.

Previous governments, both Conservative and Labour, have shown a significant shift in their planning policies once in power. The Thatcher government abandoned deregulation in the face of practical and political difficulties, many concerned with calls for stricter environmental protection. The Blair/Brown government has placed much more emphasis on promoting the market in planning and promoting development than their initial proposals in 1997 would have suggested. Notwithstanding the provision of incentives for house building, the current community-based planning policies of the Conservative party are against the interests of the house building and other development and property interests. ${ }^{1}$ The opposition of these interests is unlikely to disappear, especially in the current context where the property industry has had to cope with a severe recession and its aftermath. If a Conservative government is elected, do not be surprised that the policies as implemented prove less distinctive and less community-minded.

A further implication deserves more widespread discussion. Local communities vary enormously in their ability to organise, to prepare technical arguments and to lobby for and against specific proposals. A risk exists that community-based devolution will lead to unpopular and environmentally damaging projects being located in areas where the local community is less able to prepare a case. This being so, a communitybased planning policy implies an expansion of planning aid and similar support services for communities in need.

It is possible to identify other weaknesses in the Conservative proposals. Local authorities have a responsibility to meet regional and national housing requirements not just those specific to their district. The question of democratic control in relation to regional agencies is, in this context, a diversion. The functional requirements for regional planning, not just in relation to housing targets but also to infrastructure, will lead unelected civil servants to makes assumptions about regional planning. A gap will emerge between national policy statements and the essentially local and subregional plannings statements produced, under Conservative proposals, by local authorities or groups of local authorities. The present system at least has the advantage of bringing the regional forecasts and assumptions into the open and this will be lost. The absence of a local delivery mechanism, under democratic control, is another limitation, though the proposed Community Land Trust could be elaborated to fulfil this role.

The most important aspect of planning is not so much the detailed procedures, but the type of city we wish to create. Irrespective of whether the Conservatives win the next election or not, the repeated references to 'community' and to community control offer only a limited vision. Communities divide as well as integrate. Policies and plans need to place more emphasis on social inclusion, including the promotion of affordable housing and both more emphasis on environmental sustainability and more clarity about the relationship between planning and sustainability.

\section{Notes}

1. Estate Gazette on line, January 4, 2010, consulted February 2010 at http://www.estatesgazette.com/blogs/property-planning/2010/01/industry-launchesfight-back-against-tory-localism.html

* Correspondence Address: Barry Goodchild, Sheffield Hallam University, City Campus, Sheffield, S1 1WB. Email: b.goodchild@shu.ac.uk. 


\section{References}

Allmendinger, P. and Thomas, H. (eds) (1998) Urban planning and the British New Right. London: Routledge.

Barker, K. (2004) Delivering stability: securing our future housing needs: Review of Housing Supply - Final Report - Recommendations. London: HM Treasury.

Conservative Party (2009a) Control Shift: Returning Power to Local Communities: Responsibility Agenda. Policy Green Paper No.9. The Conservative Party at 30 Millbank: London SW1P 4DP.

Conservative Party (2009b) Strong Foundations: Building Homes and Communities. Policy Green Paper No.10. The Conservative Party at 30 Millbank: London SW1P 4DP.

Conservative Party (2010) Open source Planning Green Paper Policy Green Paper No.14. The Conservative Party at 30 Millbank: London SW1P 4DP.

Goodchild, B. (2008) Homes, Cities and Neighbourhoods. Surrey: Ashgate.

Studdert, P. (2009) Building new communities through local partnerships in CABE (corporate author) (ed.) Who should build our homes? Six experts challenge the status quo. London: CABE, 32-55. 